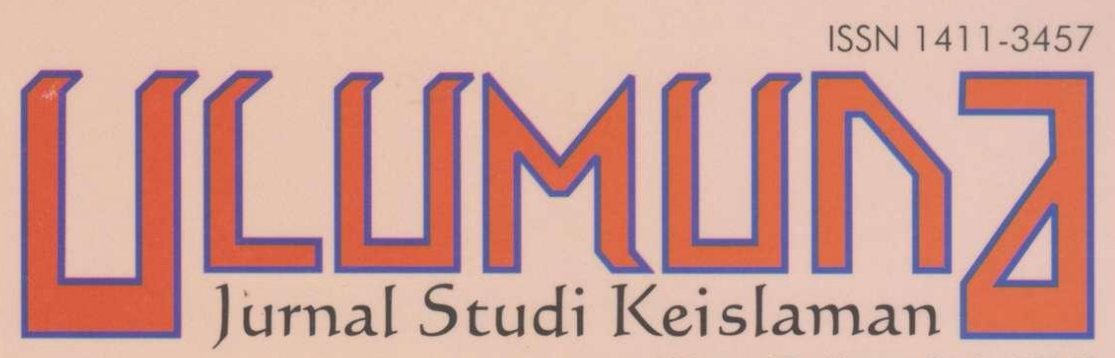

Volume 16 • Nomor 1• Juni 2012

METOdOLOGI PENEMUAN HUKUM ISLAM Munawir Haris

Pembaruan Metode Penemuan HukUm IsLam: PENDEKATAN TERPADU HUKUM ISLAM DAN SOSIAL Moh. Lutfi Nurcahyono TIPOLOGI PEMIKIRAN HUKUM ISLAM: PERgULATAN PEMIIIRAN DARI TRADISIONALIS HINGGa LIBERALIS Muhammad Harfin Zuhdi PEMBARUAN MAȘLAHAHAH DALAM MAQĀSİD AL-SHARI'AH: TELAAH HUMANISTIS TENTANG AL-KULLIYYĀT AL-KHAMSAH Zaenuddin Mansyur

MENUJU HUKUM ISLAM YANG INKLUSIF-HUMANISTIS: ANALISIS PEMIKIRAN JASSER AUDA TENTANG MAQĀSİD AL-SHARI'AAH Muhammad Salahuddin ARAH PEMBARUAN HUKUM WAKAF INDONESIA Miftahul Huda HUKUM ISLAM DALAM TRADISI LOKAL: TelaAh PEMIKIRAN TGH. M. SOleh Chambali tentang HaJI Adi Fadli Panorama Poligami dan Resistensi Perempuan DI LANGSA ACEH Muhammad Ansor PENDEKATAN HUKUM ISLAM TERHADAP JIHAD DAN TERORISME Lukman Arake 



\section{DAFTAR ISI}

\section{Pedoman Transliterasi}

1-20 • Munawir Haris, "Metodologi Penemuan Hukum Islam"

21-40 • Moh. Lutfi Nurcahyono, "Pembaruan Metode Penemuan Hukum Islam: Pendekatan Terpadu Hukum Islam dan Sosial"

41-70 • Muhammad Harfin Zuhdi, "Tipologi Pemikiran Hukum Islam: Pergulatan Pemikiran dari Tradisionalis Hingga Liberalis"

71-102 • Zaenuddin Mansyur, "Pembaruan Maslaḥah dalam Maqāṣīd al-Sharī'ah: Telaah Humanistis tentang al-Kulliyyāt al-Khamsah"

103-124• Muhammad Salahuddin,

"Menuju Hukum Islam yang Inklusif-Humanistis:

Analisis Pemikiran Jasser Auda tentang

Maqāṣīd al-Sharī'ah"

125-142 • Miftahul Huda,

"Arah Pembaruan Hukum Wakaf Indonesia"

143-162 • Adi Fadli,

"Hukum Islam dalam Tradisi Lokal:

Telaah Pemikiran TGH. M. Soleh Chambali tentang Haji"

163-188 • Muhammad Ansor,

"Panorama Poligami dan Resistensi Perempuan di Langsa Aceh"

189-222 • Lukman Arake, "Pendekatan Hukum Islam terhadap Jihad dan Terorisme"

\section{LAMPIRAN- LAMPIRAN}




\section{PEDOMAN TRANSLITERASI}

\begin{tabular}{|c|c|c|c|c|c|c|}
\hline 1 & $=$ & $\mathbf{a}$ & & $\dot{\varepsilon}$ & $=$ & $\mathbf{g}$ \\
\hline ب & $=$ & $\mathbf{b}$ & & ف & $=$ & $\mathbf{f}$ \\
\hline ت & $=$ & $\mathbf{t}$ & & ق & $=$ & $q$ \\
\hline$\dot{H}$ & $=$ & th & & ك & $=$ & $\mathbf{k}$ \\
\hline ج & $=$ & $\mathbf{j}$ & & J & $=$ & 1 \\
\hline$\tau$ & $=$ & ha & & b & $=$ & $\mathbf{m}$ \\
\hline$\dot{\tau}$ & $=$ & $\mathbf{k h}$ & & $\dot{0}$ & $=$ & $\mathbf{n}$ \\
\hline د & $=$ & $\mathbf{d}$ & & 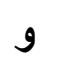 & $=$ & $\mathbf{w}$ \\
\hline$\dot{j}$ & $=$ & dh & & $\bullet$ & $=$ & $\mathbf{h}$ \\
\hline J & $=$ & $\mathbf{r}$ & & $\varepsilon$ & $=$ & , \\
\hline j & $=$ & $\mathbf{z}$ & & ي & $=$ & $\mathbf{y}$ \\
\hline س & $=$ & $\mathbf{s}$ & & & & \\
\hline 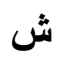 & $=$ & sh & \multicolumn{4}{|c|}{ Untuk Madd dan Diftong } \\
\hline ص ص & $=$ & $\mathbf{s}$ & i & $=$ & \multicolumn{2}{|c|}{$\bar{a}$ (a panjang) } \\
\hline ض & $=$ & d & إي & $=$ & \multicolumn{2}{|c|}{$\overline{1}$ (i panjang) } \\
\hline b & $=$ & $t$ & 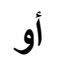 & $=$ & \multicolumn{2}{|c|}{$\overline{\mathrm{u}}$ (u panjang) } \\
\hline ظ & $=$ & z & 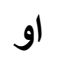 & $=$ & \multicolumn{2}{|c|}{ aw } \\
\hline$\varepsilon$ & $=$ & 6 & أي - اي & $=$ & \multicolumn{2}{|l|}{ ay } \\
\hline
\end{tabular}

Contoh penulisan dengan transilterasi:

اعوذ بالله من الشيطان الرجيم (a'üdhu bi al-Lāh min al-shaytān al-rajìm);

بسم الله الرحمن الحيم (bism al-Läh al-rahmān al-rahìm);

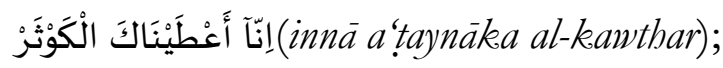

هَصََلِّ لِربِّكَ وَانْحَرْ (fasalli lirabbika wanhar);

صباح الخير (sabāh al-khayr). 


\title{
PENDEKATAN HUKUM ISLAM TERHADAP JIHAD DAN TERORISME
}

\author{
Lukman Arake \\ (STAIN Watampone Sulawesi Selatan \\ Email: lukmanarake@yahoo.co.id)
}

Abstract: There is a presumption of some circles of non-Muslims that Muslims are the spreader of terrors and terrorism throughout the world through the implementation of the concept of jihād. This assumption seemed to be justified the emerging terrorism cases involving Muslim actors, such as suicide bombings. This paper aims to clarify the issue by critically scrutinizing the true meaning of jihād rooted both in the holy book the alQur'an and sunnah of the Prophet Mubammad. Socio-historical approach is applied to better understand the holistic context of the meaning of jihād concept in both sources of Islamic teachings. The author concludes that the presumption is a misconception resulting from ignorance of certain parties about the true meaning of jihād in Islam. There is also a possibility that the misunderstanding is intentional, because the motives of abusing the dignity of Islamic teachings, especially about jihād.

Abstrak: Pada sebagian kalangan non-muslim terdapat anggapan bahwa orang Islam adalah penyebar teror dan terorisme di selurub dunia melalui implementasi konsep jihād. Anggapan itu seolab mendapatkan pembenaran dengan munculnya kasus-kasus terorisme yang melibatkan pelaku-pelaku muslim, seperti bom bunuh diri. Tulisan ini bertujuan untuk mengklarifikasi masalab tersebut dengan cara menelisik secara kritis pemaknaan jihād yang sebenarnya baik yang termaktub dalam kitab suci al-Qur'an maupun sunnah Nabi Mubammad saw. Pendekatan sosial-historis diterapkan untuk lebih memahami konteks bolistik bagi pemaknaan konsep jihad dalam dua sumber ajaran Islam itu. Penulis berkesimpulan babwa anggapan tersebut adalab suatu kesalahpahaman akibat dari ketidaktahuan pibak-pibak tertentu tentang makna jihād yang sebenarnya dalam Islam. Tidak tertutup kemungkinan bahwa kesalahpahaman itu disengaja, karena adanya motif-motif untuk mencederai keluburan ajaran Islam, khususnya tentang jihād.

Keywords: jihād, terorisme, bukum Islam, nilai-nilai perdamaian. 
TERDAPAT beberapa kekeliruan yang perlu diklarifikasi terutama terkait dengan pemaknaan jihad di dalam Islam. Pemaknaan perang atau jihad yang banyak ditulis oleh sarjana Barat cenderung mencampuradukkan antara term terorisme dengan jihad. Semua itu dilakukan karena barangkali berangkat dari kebencian dan tidak adanya rasa empati. Padahal sesungguhnya jihad bukanlah terorisme. Jika orang tidak mengerti ajaran Islam yang sesungguhnya maka tentu akan mencampuradukkan antara makna jihad dengan terorisme hanya dengan melihat beberapa kelompok fanatik yang menjadikan term jihad sebagai pelindung gerakan aktivitas yang mereka lakukan. Mereka menganggap bahwa apa yang mereka lakukan adalah jihad yang dibenarkan agama termasuk membunuh, menculik, merusak, dan membajak kapal terbang. Tetapi kebenaran tetap kebenaran yang mesti ditegakkan, sehingga harus dijelaskan bahwa antara terorisme dengan jihad tidak ada keterkaitan sedikit pun.

Jihad di dalam Islam memiliki landasan yang kuat yakni alQur'an dan hadis yang kemudian pembumiannya telah dicontohkan oleh nabi dan sahabatnya. Oleh karenanya, jihad di dalam Islam bila ditilik dari sudut pandang hukum Islam dan sejarah, maka teori dan aplikasinya akan sangat jauh berbeda dengan terorisme. Perbedaannya bagaikan langit dan bumi. Gerakan terorisme tidak membedakan mana yang hak dan mana yang batil. Pelakunya selalu merasa haus dengan kekerasan dan darah sehingga bila korban berjatuhan barulah kemudian mereka merasa puas, dan tentu perilaku seperti itu dikecam keras oleh Islam.

Karena pemaknaan jihad di dalam Islam sangat luas dan monolitik, maka jihad dapat diartikan sebagai usaha secara penuh yang dikerahkan oleh seseorang dalam melakukan perbaikan. Oleh karenanya, mengajak seseorang ke jalan yang benar dengan tulus dan lemah lembut adalah jihad. Melakukan perbaikan di bidang pendidikan dan kebudayaan adalah jihad. Melakukan perbaikan peningkatan ekonomi dan sosial masyarakat adalah jihad. Berbuat baik kepada kedua orangtua, anak, dan isteri adalah jihad. Memberikan perhatian terhadap kehidupan sosial masyarakat adalah jihad. Mengajak kepada kebenaran serta mencegah kemungkaran adalah jihad. Berbuat 
baik dan berlaku adil kepada non muslim yang tidak memerangi orang Islam adalah jihad. Bahkan berbuat baik dan berlaku lemah lembut terhadap hewan-hewan, tumbuh-tumbuhan, dan hal-hal yang natural adalah jihad.

Al-Qur'an ketika memaknai jihad (jihad besar) yang dimaksud adalah jihad dengan al-Qur'an, dan bukan jihad dengan kekerasan apalagi peperangan. Allah berfirman: "Maka janganlah kamu mengikuti orang-orang kafir, dan berjihadlah terhadap mereka dengan al-Qur'an dengan jihad yang besar". (Qs. al-Furqān [25]: 52). Bahkan al-Qur'an ketika berbicara tentang jihad, justeru yang ditonjolkan adalah jihad yang erat kaitannya dengan jiwa dan harta, bahkan mendahulukan konsep jihad dengan harta. Allah berfirman:

Dan orang-orang yang beriman dan berhijrah serta berjihad pada jalan Allah, dan orang-orang yang memberi tempat kediaman dan memberi pertolongan (kepada orang-orang Muhajirīn), mereka itulah orangorang yang benar-benar beriman. Mereka memperoleh ampunan dan rezki (nikmat) yang mulia. (Qs. al-Anfâl [8]: 74).

Berkaitan dengan konsep jihad ini, Allah juga berfirman dalam Qs. al-Șaff (37): 10-11:

Hai orang-orang yang beriman, sukakah kamu Aku tunjukkan suatu perniagaan yang dapat menyelamatkanmu dari azab yang pedih? (yaitu) kamu beriman kepada Allah dan Rasul-Nya dan berjihad di jalan Allah dengan harta dan jiwamu. Itulah yang lebih baik bagimu, jika kamu mengetahui.

Di sisi lain, bila jihad dimaknai sebagai perang maka merupakan objek yang sangat panjang. Namun pada intinya adalah bahwa jihad yang berarti perang hanya dapat dilakukan dengan tujuan membela diri termasuk membela tanah air dan masyarakat yang teraniaya. Sebagaimana Allah berfirman dalam Qs. al-Hajj (22): 39-40:

Telah diizinkan (berperang) bagi orang-orang yang diperangi, karena sesungguhnya mereka telah dianiaya. Dan sesungguhnya Allah benarbenar Maha Kuasa menolong mereka itu, (yaitu) orang-orang yang telah diusir dari kampung halaman mereka tanpa alasan yang benar, kecuali karena mereka berkata: "Tuhan kami hanyalah Allah". Dan sekiranya Allah tiada menolak (keganasan) sebagian manusia dengan sebagian yang lain, tentulah telah dirobohkan biara-biara Nasrani, gereja-gereja, rumah-rumah ibadah orang Yahudi dan masjid-masjid, yang di dalamnya banyak disebut nama Allah. Sesungguhnya Allah pasti menolong orang yang menolong (agama)-Nya. Sesungguhnya Allah benar-benar Maha Kuat lagi Maha Perkasa. 
Dengan sangat jelas, al-Qur'an memberikan penegasan terkait dengan prinsip-prinsip yang mesti diperhatikan dalam mempertahankan jati diri dari serangan musuh dengan melakukan perlawanan demi mempertahankan hidup. Dan itulah alasan bolehnya perang di dalam Islam. Ibn Qayyim al-Jawziyyah mengklasifikasikan jihad ke dalam empat bagian, yaitu:

1. Jihad dalam menghadapi hawa nafsu.

2. Jihad dalam menghadapi setan-setan.

3. Jihad dalam menghadapi orang-orang kafir dan orang-orang munafik.

4. Jihad dalam menghadapi kesewenangan, kezaliman, dan kejahatan. ${ }^{1}$

Kemudian Ibn Qayyim al-Jawziyyah menjelaskan secara detail empat poin itu sehingga mencapai tiga belas tingkatan jihad. Lalu beliau sampai pada satu kesimpulan bahwa jihad dengan menggunakan fisik (peperangan) hanya satu saja. Oleh karena itu, aktivitas yang dilakukan untuk menjunjung tinggi nilai-nilai kemanusiaan serta memerangi kebatilan dianggap sebagai jihad. Jadi, tidak semua jihad di jalan Allah harus dimaknai dengan peperangan, karena jihad yang berarti perang sifatnya sangat adaptabel sehingga hanya terjadi bila kondisi yang menuntut demikian dan berakhir ketika faktor pemicu terjadinya perang telah tiada. Tetapi, karena banyak orang tidak memahami makna jihad yang sesungguhnya sehingga dalam prakteknya terjadi penyalahgunaan term. Walau demikian, semua itu tidak mempengaruhi nilai-nilai jihad yang sebenarnya kendati banyak terjadi rekayasa bahwa anarkisme dan terorisme tiada lain kecuali bagian dari jihad.

\section{Jihad Bukan Terorisme}

Adanya kecenderungan mengidentikkan jihad dengan gerakan terorisme sesungguhnya bertujuan untuk menutup rapat-rapat hak setiap orang dalam menentukan hidupnya. Ketika suatu bangsa yang tertindas dan terjajah tidak diberi hak untuk berjuang dan berjihad melawan kesewenangan para

${ }^{1}$ Ibn Qayyim al-Jawziyyah, Zād al-Ma'ād, jilid 3 (Bayrūt: Mu'assasah alRisālah, 1994), 9. Lihat juga bukunya, Rawdah al-Muḅibbin (Bayrūt: Dār alKutub al-'Ilmiyyah, 1992), 478. 
penjajah akibat adanya jihad selalu diidentikkan dengan terorisme sesungguhnya telah melanggar nilai-nilai kemanusiaan dan konstitusi yang ada. Karena baik dalam konteks hukum konvensional maupun hukum agama banyak ditegaskan bahwa orang tertindas akibat penjajahan dan kezaliman berhak membela diri dan mempertahankan tanah airnya. ${ }^{2}$

Dewasa ini telah terjadi revolusi yang cenderung memutarbalikkan fakta dalam memaknai suatu term pemikiran. Akibatnya, banyak orang sudah tidak mengerti mana yang benar dan mana yang salah. Lemahnya kepribadian, baik terhadap diri sendiri maupun teradap nilai-nilai integralistik agama mengakibatkan suatu bangsa yang membela jiwa dan tanah airnya dari kesewenangan para penjajah justeru dianggap sebagai pembangkang bahkan teroris. Sementara pelaku kejahatan yang disaksikan dengan kasat mata oleh semua orang tidak diapaapakan bahkan dijuluki sebagai pahlawan.

Adanya anggapan sebagian orang bahwa Islam adalah agama yang identik dengan darah adalah sesuatu yang aneh. Memutarbalikkan fakta dengan melakukan pemaknaan term tertentu dengan tidak secara proporsional dianggap tidak ilmiah, apalagi jika yang bersangkutan memang pada dasarnya tidak mengerti. Wajar jika orang bijak mengatakan bahwa untuk memberikan penilaian baik terhadap satu term maupun terhadap ideologi tertentu yang kemudian diekspos ke tengah publik maka pertama kali yang mesti diperhatikan ialah memahami maksud term dan ideologi itu sendiri secara baik. Memahami term dan ideologi yang dimaksudkan di sini ialah mencakup undangundang, prinsip-prinsip serta nilai-nilai yang dijadikan sebagai platform term atau ideologi yang dimaksud.

2Dalam Islam, seseorang tidak boleh disakiti atau ditangkap selama mereka tidak melakukan aktivitas yang melanggar hukum. Dan hal ini sudah menjadi kaedah umum di dalam Islam yakni "al-bara'ah al-asliyab”. Artinya seseorang pada dasarnya merdeka tidak terbebani oleh apapun kecuali dengan adanya ketentuan hukum itu sendiri. Atau dalam bahasa hukum konvensional disebut "tidak ada kriminal dan bukuman kecuali dengan bukum itu sendiri”. Lihat, al-Qarafi, Anwar ul-Buruk fi Anwai al-Furuk, jilid 1 (Bayrut: Dār al-Kutub al-'Tlmiah, 1998),128. Al-Mustașar 'Umar Sharîf, Al-Hukm wa al-Idārah fì al-Dawlah al-Islämiyyah (Kairo: Ma'had al-Dirāsah al-Islāmiyyah, 1986), 156. 
Selain yang disebutkan, harus betul-betul paham siapa pembawa ideologi itu, bagaimana perilaku dan kepribadiannya serta sejauh mana pembuktian yang telah dilakukannya dalam mengimplementasikan nilai-nilai ideologi yang dibawanya. Begitu pula ideologi tersebut harus disikapi dengan melihat sejauh mana pengaruhnya terhadap diri pemeluknya dan masyarakat yang ada pada umumnya. Dan apakah pengaruh ideologi itu berakhir dengan berakhirnya orang yang membawanya atau kah pengaruh tersebut tetap ada dan bertahan kendati orang-orang yang membawanya telah tiada. Lalu yang terakhir ialah bahwa apakah ideologi itu mengandung unsur pemaksaan terhadap orang lain untuk dijadikan sebagai pegangan, atau kah orang-orang memeluknya dengan senang hati bila ia mau dan tidak diapaapakan jika mereka tidak suka.

Semua itu mesti dilakukan oleh setiap orang yang mencoba mengaitkan antara jihad di dalam Islam dengan terorisme. Benarkah Islam adalah agama yang mengajarkan poin-poin yang disebutkan di atas? Atau kah Islam justeru menjunjung tinggi nilai-nilai kedamaian, toleransi, persaudaraan, dan nilai-nilai kemanusiaan? Tentu jawabannya adalah yang terakhir. Jadi, memahami Islam sebagai agama rabmatan li al-alamin harus dengan bijak, tidak membabi-buta apalagi dengan sikap emosional dan rasa benci. Kalau itu yang terjadi maka tentu sikap tersebut dianggap zalim karena tidak proporsional seperti yang dibahasakan al-Qur'an bahwa: "Mereka-mereka itu wahai Muhammad sesungguhnya tidak mendustakan kamu, akan tetapi mereka orang-orang zalim justeru mengingkari ayat-ayat Allah”. (Qs. al-An'am [6]: 33).

Dan perlu diketahui bahwa jihad yang diwajibkan itu seperti apa? Karena sesungguhnya jihad atau perang hanya dapat dilakukan dalam kondisi tertentu misalnya melawan serangan musuh demi menjaga kemaslahatan umat Islam. Allah menegaskan: "Diwajibkan atas kamu berperang, padahal berperang itu adalah sesuatu yang kamu benci. Boleh jadi kamu membenci sesuatu, padahal ia baik bagimu, dan boleh jadi (pula) kamu menyukai sesuatu, padahal ia buruk bagimu; Allah mengetahui, sedang kamu tidak mengetahui”. (Qs. al-Baqarah [2]: 216). 


\section{Menyebarkan Islam dengan kekerasan atau} menyampaikannya dengan pedang tidaklah termasuk jihad. Akan tetapi jihad adalah cara untuk menangkal serangan musuh, menangkal kezaliman, menjaga orang-orang lemah sesuai dengan maslahah dengan penuh perhitungan setelah ada keputusan dari pemerintah atau kepala negara. Adanya jihad di dalam Islam bukan karena faktor perbedaan agama, tetapi jihad dilakukan karena adanya peperangan dan permusuhan. Begitu pula tidaklah dianggap jihad bila tujuannya untuk memaksa orang lain memeluk Islam karena hal itu dilarang dalam agama. Allah berfirman dalam Qs. al-Baqarah (2): 256:

Tidak ada paksaan untuk (memasuki) agama (Islam); sesungguhnya telah jelas jalan yang benar daripada jalan yang sesat. Karena itu barang siapa yang ingkar kepada Taghut (setan disembah selain Allah) dan beriman kepada Allah, maka sesungguhnya ia telah berpegang kepada buhul tali yang amat kuat yang tidak akan putus. Dan Allah Maha mendengar lagi Maha Mengetahui.

Dasar hubungan orang Islam dengan non muslim adalah perdamaian dan bukan perang. Ini adalah penegasan mayoritas ulama Islam. ${ }^{3}$ Allah berfirman: "Hai orang-orang yang beriman, masuklah kamu ke dalam Islam secara keseluruhan, dan janganlah kamu menuruti langkah-langkah setan. Sesungguhnya setan itu musuh yang nyata bagimu". (Qs. al-Baqarah [2]: 208). "Kecuali orang-orang yang meminta perlindungan kepada suatu kaum, yang antara kamu dan kaum itu telah ada perjanjian (damai), atau orang-orang yang datang kepada kamu sedang hati mereka merasa keberatan untuk memerangi kamu dan memerangi kaumnya. Kalau Allah menghendaki, tentu dia memberi kekuasaan kepada mereka terhadap kamu, lalu pastilah mereka memerangimu. Tetapi jika mereka membiarkan kamu, dan tidak memerangi kamu serta mengemukakan perdamaian kepadamu, maka Allah tidak memberi jalan bagimu (untuk menawan dan membunuh) mereka". (Qs. al-Nisā [4]: 90). "Hai orang-orang yang beriman, apabila kamu pergi (berperang) di jalan Allah, maka telitilah dan janganlah kamu mengatakan kepada orang yang mengucapkan "salam" kepadamu: "Kamu

${ }^{3}$ Lihat, 'Abd al-Wahab Khallāf, Al-Siyāsah al-Sharíyyah, (Kairo: Dār alQalām, 1988), 56. 
bukan seorang mukmin" (lalu kamu membunuhnya), dengan maksud mencari harta benda kehidupan di dunia, karena di sisi Allah ada harta yang banyak". (Qs. al-Nisā [4]: 94). "Dan jika mereka condong kepada perdamaian, maka condonglah kepadanya dan bertawakkallah kepada Allah. Sesungguhnya Dialah yang Maha Mendengar lagi Maha Mengetahui". (Qs. al-Anfāl [8]: 61). "Allah tidak melarang kamu untuk berbuat baik dan berlaku adil terhadap orang-orang yang tiada memerangimu karena agama, dan tidak (pula) mengusir kamu dari negerimu. Sesungguhnya Allah menyukai orang-orang yang berlaku adil". (Qs. al-Mumtahanah [60]: 8).

Ayat-ayat tersebut dipertegas lagi oleh hadis Nabi:

Wahai sekalian manusia, janganlah engkau selalu berangan-angan bertemu dengan musuh, dan mintalah kepada Allah agar senantiasa melimpahkan nikmat ketentraman dan kedamaian. Namun jika kamu bertemu (berperang) dengan musuh maka bersabarlah, dan ketahuilah bahwa surga itu ada di bawah naungan pedang. ${ }^{4}$

Nabi melarang orang Islam berharap bertemu dengan musuh oleh karena perang seperti yang disinggung hanya dapat dilakukan untuk menghadang serangan musuh, mempertahankan tanah air dan kehormatan, bukan untuk menindas bangsa lain. Itulah sebabnya dalam banyak kesempatan, para ulama memandang bahwa setiap orang terjaga kehormatannya agar dapat memikul beban kehidupan, dan peperangan terjadi di luar kemauan manusia sehingga hanya dibolehkan untuk menghadang tindak kejahatan yang terjadi. ${ }^{5}$ Semua itu dapat terlihat dari perang yang dilakukan nabi sebanyak 27 kali. Kesemuanya tidak terjadi kecuali untuk mempertahankan eksistensi diri, agama dan pemeluknya. Dan non muslim dari orang-orang musyrik primitif, bangsa Rum dan bangsa Persia yang memusuhi orang-orang Islam sehingga mereka pun terpaksa melakukan perlawanan.

${ }^{4}$ Al-Bukhari, Șạ̧ị̣ al-Bukhari, jilid 1 (Bayrut: Dār Ibn Kathir, 1987), 1082. Al-Nawawiy, Sharh Șaḥị̧ al-Muslim, jilid 14 (Bayrut: Dār Ihya' Atturath al-'Arabiy, 1392), 207.

5Imam Malik mengatakan: Tidak sepantasnya bagi seorang Muslim menumpahkan darahnya kecuali dalam kebenaran, dan tidak sepantasnya pula menumpahkan darah orang lain kecuali dalam kebenaran. 
Perang dalam Islam diperbolehkan dalam situasi dan kondisi tertentu. Beberapa kondisi bolehnya perang, yaitu:

- Dalam kondisi di mana orang-orang Islam diperangi baik secara perorangan maupun kelompok termasuk terhadap negara mereka dan hak-haknya.

- Dalam kondisi membela orang-orang yang dizalimi baik secara perorangan maupun secara kelompok. Allah berfirman: "Mengapa kamu tidak mau berperang di jalan Allah dan (membela) orang-orang yang lemah baik laki-laki, wanita-wanita maupun anak-anak yang semuanya berdoa: "Ya Tuhan kami, keluarkanlah kami dari negeri ini (Mekah) yang zalim penduduknya dan berilah kami pelindung dari sisi Engkau, dan berilah kami penolong dari sisi Engkau”. (Qs. al-Nisā [4]: 75). Dalam hal ini Nabi telah menolong kabilah Huza'ah dari serangan Quraysh dan sekutunya yakni Baniy Baker akibat mereka menyerang kelompok Huza'ah dalam perjanjian damai Hudaibiyah setelah kabilah Huza'ab minta bantuan kepada nabi, dan Nabi pun menyetujui perjanjian untuk membela kelompok tertidas yang dikenal dengan perjanjian hilf al-fudul yang diadakan antara Quraysh dengan kabilah-kabilah Arab untuk menolong yang dizalami, yang tertindas dan melindungi yang lemah. ${ }^{6}$

- Dalam kondisi di mana perjanjian damai tidak diindahkan atau diabaikan syarat-syaratnya. Atau para musuh melakukan konfrontasi terhadap orang-orang Islam. Allah berfirman: "Jika mereka merusak sumpah (janji) nya sesudah mereka berjanji, dan mereka mencerca agamamu, maka perangilah pemimpin-pemimpin orang-orang kafir itu, karena sesungguhnya mereka itu adalah orang-orang (yang tidak dapat dipegang) janjinya, agar supaya mereka berhenti”. (Qs. at-Taubah [9]: 12). "Dan jika kamu khawatir akan (terjadinya) pengkhianatan dari suatu golongan, maka kembalikanlah perjanjian itu kepada mereka dengan cara yang jujur. Sesungguhnya Allah tidak menyukai orang-orang yang berkhianat". (Qs. al-Anfāl [8]: 58).

'Lihat, Ibn Hajar, Fatḥ al-Bārī, jilid 5 (Bayrut: Dār al-Ma'rifah, 1379 H), 337. 
Berikut adalah teks-teks agama terkait dengan perang, tujuannya, syarat-syaratnya, prosesnya serta kapan harus diakhiri, dan apa saja konsekuensinya?

\section{Pertama, Ayat al-Qur'an}

- "Kemudian jika mereka berhenti (dari memusuhi kamu), maka sesungguhnya Allah Maha Pengampun lagi Maha Penyayang. Dan perangilah mereka itu, sehingga tidak ada fitnah lagi dan (sehingga) ketaatan itu hanya semata-mata untuk Allah. Jika mereka berhenti (dari memusuhi kamu), maka tidak ada permusuhan (lagi), kecuali terhadap orangorang yang zalim". (Qs. al-Baqarah [2]: 192-3).

- "Diwajibkan atas kamu berperang, padahal berperang itu adalah sesuatu yang kamu benci. Boleh jadi kamu membenci sesuatu, padahal ia baik bagimu, dan boleh jadi kamu menyukai sesuatu, padahal ia buruk bagimu; Allah mengetahui, sedang kamu tidak mengetahui". (Qs. AlBaqarah [2]: 216).

- "Mereka bertanya kepadamu tentang berperang pada bulan Haram. Katakanlah: "Berperang dalam bulan itu adalah dosa besar; tetapi menghalangi (manusia) dari jalan Allah, kafir kepada Allah, (menghalangi masuk) Masjidil Haram dan mengusir penduduknya dari sekitarnya, lebih besar (dosanya) di sisi Allah. Dan berbuat fitnah lebih besar (dosanya) daripada membunuh. Mereka tidak henti-hentinya memerangi kamu sampai mereka (dapat) mengembalikan kamu dari agamamu (kepada kekafiran), seandainya mereka sanggup". (Qs. Al-Baqarah [2]: 217).

- "Dan berapa banyaknya nabi yang berperang bersama-sama mereka sejumlah besar dari pengikut (nya) yang bertakwa. Mereka tidak menjadi lemah karena bencana yang menimpa mereka di jalan Allah, dan tidak lesu dan tidak (pula) menyerah (kepada musuh). Allah menyukai orang-orang yang sabar". (Qs. Ali Imran [3]: 146).

- "Maka Tuhan mereka memperkenankan permohonannya (dengan berfirman): "Sesungguhnya Aku tidak menyianyiakan amal orang-orang yang beramal di antara kamu, baik laki-laki atau perempuan, (karena) sebagian kamu adalah 
keturunan dari sebagian yang lain. Maka orang-orang yang berhijrah, yang diusir dari kampung halamannya, yang disakiti pada jalan-Ku, yang berperang dan yang dibunuh, pastilah akan Aku hapuskan kesalahan-kesalahan mereka dan pastilah Aku masukkan mereka ke dalam surga yang mengalir sungaisungai di bawahnya, sebagai pahala di sisi Allah. Dan Allah pada sisi-Nya pahala yang baik." (Qs. Ali Imrān [3]: 195).

- "Karena itu hendaklah orang-orang yang menukar kehidupan dunia dengan kehidupan akhirat berperang di jalan Allah. Barangsiapa yang berperang di jalan Allah, lalu gugur atau memperoleh kemenangan Maka kelak akan kami berikan kepadanya pahala yang besar". (Qs. al-Nisā [4]: 74).

- "Mengapa kamu tidak mau berperang di jalan Allah dan (membela) orang-orang lemah baik laki-laki, perempuan maupun anak-anak yang berdoa: "Ya Tuhan kami, keluarkan kami dari negeri ini (Mekah) yang zalim penduduknya dan berilah kami pelindung dari sisi Engkau, dan berilah kami penolong dari sisi Engkau". (Qs. al-Nisā [4]: 75).

- "Dan jika mereka condong kepada perdamaian, maka condonglah kepadanya dan bertawakkallah kepada Allah. Sesungguhnya Dia-lah yang Maha Mendengar lagi Maha Mengetahui”. (Qs. al-Anfāl [8]: 61).

- "Telah diizinkan (berperang) bagi orang-orang yang diperangi, karena sesungguhnya mereka telah dianiaya. Dan sesungguhnya Allah, benar-benar Maha Kuasa menolong mereka itu, (yaitu) orang-orang yang telah diusir dari kampung halaman mereka tanpa alasan yang benar, kecuali karena mereka berkata: "Tuhan kami hanyalah Allah". Dan sekiranya Allah tiada menolak (keganasan) sebagian manusia dengan sebagian yang lain, tentulah telah dirobohkan biarabiara Nasrani, gereja-gereja, rumah-rumah ibadah orang Yahudi dan masjid- masjid, yang di dalamnya banyak disebut nama Allah. Sesungguhnya Allah pasti menolong orang yang menolong (agama)-Nya. Sesungguhnya Allah benar-benar Maha Kuat lagi Maha Perkasa”. (Qs. al-Hajj [22]: 39-40).

\section{Kedua, Hadis Nabi}


- Hadis Abū Hurayrah bahwasanya Nabi mengatakan: "Allah menanggung orang-orang yang berjihad di jalan-Nya, dia tidak keluar dari rumahnya kecuali karena jihad dan pembenaran terhadap kalimat-kalimat-Nya, maka Allah akan memasukkannya ke dalam surga, atau akan dikembalikan ke rumahnya bersama apa yang telah ia dapatkan berupa pahala besar atau harta rampasan perang". 7

- Riwayat dari Said bin Zaid bin Saad al-Ashhali bahwasannya Nabi pernah dihadiahi sebuah pedang dari Najran, namun setelah itu pedang tersebut diberikan kepada Muhammad bin Muslimah. Nabi mengatakan kepadanya: "Berjihadlah di jalan Allah dengan pedang ini, dan apabila orang-orang berselisih maka pukulkanlah pedangmu itu di batu kemudian masuklah ke dalam rumahmu sampai engkau dibunuh oleh orang yang bersalah atau engkau didatangi ajal kematian". ${ }^{8}$

- Hadis riwayat Abdullah bin Amru. Beliau mengatakan: seorang lelaki datang kepada Nabi dan mengatakan: "Aku ingin berjihad." Nabi mengatakan kepadanya: "Apakah orangtuamu masih hidup?" Lelaki itu mengatakan masih hidup. Nabi mengatakan: "kepadanyalah engkau berjihad". 9

Dari semua teks tadi, sangatlah jelas bahwa perang di dalam Islam hanya disyariatkan untuk menjamin keamanan proses dakwah serta menahan serangan para musuh. Perang hanyalah untuk mempertahankan jiwa dan harta kekayaan yang dimiliki. Teks-teks tersebut juga menjelaskan tentang proses dan undangundang perang yang mesti dipatuhi, misalnya harus diumumkan dan disampaikan kepada musuh. Maka dari itu, dalam konteks agama diharamkan melakukan agresi dengan diam-diam dan mendadak apalagi membabi buta. Islam melarang membunuh orang-orang yang sudah lanjut usia, wanita, anak-anak, dan para buruh yang tidak terlibat dalam perang. Islam juga melarang memutilasi jasad musuh, dan mewajibkan untuk mengubur mereka dengan baik. Hal itu dapat dilihat dari wasiat Nabi yang

${ }^{7}$ Muhammad bin Futuh al-Humaidi, Al-Jam'u Bayn al-Ṣạihain al-Bukhäri wa Muslim, jilid 3 (Bayrut: Dār Ibn Hazm, 2002), 128.

${ }^{8}$ Alauddin Ali bin Hisam, Kanzul Ummal, jilid 11 (Bayrut: Mu'assasah alRisālah, 1981), 213.

'Al-Bukhārī, Șahih al-Bukhārì, jilid 3 (Dār Ibn Kathir, 1987), 1094. 
mengatakan: "Berangkatlah ke medan perang dengan kalimat bismi al-Läh, wa bi al-Läh, wa fi sabililläh, engkau memerangi orang-orang yang ingkar kepada Allah (kafir). Nabi mengutusmu ke medan perang, jangan melakukan sesuatu yang melampaui batas, jangan engkau memutilasi jasad musuh, jangan membunuh anak kecil, jangan membakar atau merusak rumah ibadah (gereja), dan jangan pula merusak pepohonan". Dalam wasiat lain disebutkan: "Jangan engkau membunuh wanita dan para pencari upah". ${ }^{10}$

Jelaslah bahwa perang di dalam Islam sangat manusiawi, penuh dengan kemuliaan dan kebajikan. Oleh karena itu, ketika perang sedang bergejolak lalu para musuh ingin melakukan perjanjian damai maka pada saat itu pula orang-orang Islam diperintahkan untuk menerima tawaran perdamaian itu. Nabi dan para sahabatnya telah membumikan nilai-nilai tersebut. Mereka selalu berpesan kepada para panglima perangnya tentang apa yang mesti dilakukan ketika perang sedang terjadi. Indikasinya adalah wasiat Abū Bakr kepada pasukan yang dipimpin oleh Usama bin Zaid. Beliau mengatakan: "Wahai orang-orang, berhentilah sejenak, aku ingin menyampaikan sepuluh pesan kepada kamu sekalian, dan jagalah pesan-pesan itu". ${ }^{11}$ Sepuluh pesan yang dimaksud adalah; jangan engkau berhkianat, jangan melampaui batas, jangan curang, jangan memutilasi, jangan membunuh anak kecil, jangan membunuh orang tua yang sudah lanjut usia, jangan merusak tanaman, jangan membakar tanaman, jangan memotong pohon yang sedang berbuah, dan jangan meyembelih kambing, sapi dan binatang apa saja kecuali untuk dimakan.

Lebih lanjut Abū Bakr berwasiat: "Dan kamu sekalian akan melewati sekelompok orang yang perhatiannya terkonsentrasi pada rumah ibadah mereka. Maka biarkan saja mereka dan apa yang sedang mereka lakukan. Kamu sekalian juga akan melewati sekelompok orang yang akan memberimu bejana di mana di dalamnya terdapat berbagai macam makanan, dan jika engkau

${ }^{10} \mathrm{Ibn}$ Hibban, Șabih Ibn Hibbān, jilid 11(Bayrut: Mu'assasah al-Risalah, 1993), 42.

${ }^{11}$ Muhammad Husayn Haykal, Al-Șiddīq Abū Bakr (Kairo: Matba'ah Misr, $1361 \mathrm{H})$, 98-9. 
memakan sebahagian dari makanan itu maka bacalah bismi alLäh. Berangkatlah dengan membaca bismi al-Läh semoga Allah menghindarkanmu semua dari kekalahan, keguguran dan menghindarkanmu dari segala penyakit". ${ }^{12}$ Dalam riwayat lain disebutkan bahwa Abū Bakr juga berpesan dengan hal yang sama kepada bala tentara Islam yang dipimpin oleh panglima Yazid bin Abī Sufyan.

Islam telah menetapkan beberapa kaedah hukum perang sekaligus membentuk sebuah sistem paripurna tentang perang yang garis besarnya berasas pada belas kasih dan perlakuan baik terhadap musuh. Nilai-nilai itulah yang dijadikan orang-orang Islam sebagai dasar sepanjang perjuangannya dalam menghadapi musuh-musuhnya, dan beratus-ratus tahun sebelum negara abad modern mengenal sistem dan prinsip-prinsip tersebut.

Undang-undang perang yang tertera dalam hukum internasional Eropa baru dimulai sejak tiga abad lalu sebagai hasil imitasi dari syariat Islam. Kendati orang-orang Eropa masih tetap bermuara pada kaedah perang tradisional sampai pertengahan abad ke-19 M. Dalam tataran negara-negara bangsa di Eropa baru memulai mengkodifikasi undang-undang perang dalam perjanjian yang mereka lakukan. Undang-undang pertama adalah undang-undang tentang Kelautan di Paris tahun 1856, kemudian disusul dengan kesepakatan Jenewa tahun 1864 M terkait dengan perlakuan terhadap orang terluka dan menderita sakit dalam peperangan. Setelah itu disusul lagi dengan peraturan Sant Butrosburj tentang pelarangan menggunakan peluru peledak. Lalu kemudian disusul dengan dua kesepakatan perang laut dan darat sebagai hasil konvensi konferensi Lahai 1899 dan 1907. Kemudian disusul lagi dengan kesepakatan Washington tahun 1922 tentang Perang Bawah Laut. Kemudian kesepakatan Jenewa tahun 1949 yang secara khusus terkait dengan masalah memperlakukan orang terluka, tawanan perang serta perlindungan terhadap masyarakat sipil. ${ }^{13}$

Kesemua perjanjian yang disinggung itu ada yang perlu digarisbawahi yakni semua kesepakatan dalam aplikasinya

${ }^{12}$ Ibid.

${ }^{13} \mathrm{Abū}$ Hef, Al-Qanūn al-Dawli al-'Am, volume 4 (Kairo: Mansya'ah alMa’ārif, 1959), 650-1. 
ternyata tidak diberlakukan kecuali ketika terjadi perang antara dua negara yang memang sebelumnya sudah menandatangani perjanjian atau kesepakatan yang dimaksud. Adapun bagi negara yang tidak melakukan penandatanganan maka tidak ada belas kasih, tidak ada peraturan yang mesti ditaati. Mereka dapat melakukan apa saja yang meraka inginkan termasuk menahan masyarakat sipil, melakukan perampokan, dan pembunuhan. ${ }^{14}$ Sementara dari sisi lain telah dipertegas bahwa tujuan perang di dalam Islam adalah, Pertama, elakukan perlawanan pembelaan serta mempertahankan jiwa. Kedua, menjaga stabilitas dakwah kepada Allah serta memberikan kesempatan kepada orang-orang lemah yang ingin memeluk Islam. Ketiga, menegakkan kebenaran dan keadilan.

Begitu pula bahwa syarat-syarat perang mesti memenuhi halhal berikut: 1). Kejelasan cara dan tujuan. 2). Tidak ada perang kecuali terhadap orang yang terlibat perang, dan tidak boleh membunuh orang-orang sipil. 3). Jika musuh cenderung kepada perdamaian atau ingin mengakhiri peperangan maka tidak ada permusuhan kecuali kepada orang-orang zalim. 4). Menjaga eksistensi para tahanan serta memberlakukan mereka dengan sebaik-baiknya sebagai manusia. 5). Menjaga lingkungan termasuk pelarangan membunuh binatang tanpa alasan yang jelas, tidak boleh membakar pepohonan, tidak boleh merusak tanaman dan buah-buahan, tidak boleh mengotori air bersih serta polusi sumber air dan tidak boleh meruntuhkan tempat tinggal atau rumah-rumah. 6). Menjaga kebebasan beragama bagi orang-orang yang ada di rumah ibadah serta para pendeta dengan tidak mengganggu mereka.

Berangkat dari sekian penegasan tadi, maka aktivitas yang dilakukan dengan kekerasan untuk mencapai suatu tujuan politik yang banyak digembor-gemborkan media massa di Eropa dengan term "teroris" lalu kemudian diidentikkan dengan Islam adalah konklusi yang keliru. Term kekerasan dalam konteks Islam kontradiksi dengan term "lemah lembut". Dalam satu hadis yang diriwayatkan oleh Muslim disebutkan bahwa Nabi mengatakan: "Sesungguhnya Allah memberikan nilai tambah terhadap perilaku lemah lembut dan tidak memberikan kepada

${ }^{14}$ Ibid. 
perilaku kekerasan". ${ }^{15}$ Dalam hadis lain seperti yang dijelaskan dalam kitab al-Muwatta' bahwa sesungguhnya Nabi telah menegaskan bahwa: "Allah Maha Lembut dan menyukai kelembutan dan rida terhadapnya sekaligus memberikan dorongan untuk melakukannya, dan tidak memberikan dorongan untuk melakukan kekerasan"16. Dengan demikian, falsafah kelembutan adalah merupakan cara berinteraksi dalam satu komunitas masyarakat yang meliputi semua dimensi hidup. Sementara kekerasan merupakan konsep yang sangat bertentangan dengan konsep lemah lembut.

\section{Benarkah Islam Tersebar dengan Pedang}

Angggapan bahwa Islam dapat menyebar ke seluruh pelosok dunia karena kekuatan pedang dan kekerasan seperti yang banyak ditulis oleh orang-orang fanatik dan benci terhadap Islam, lalu kemudian diekspos di media massa di Barat, adalah anggapan yang keliru. Betapa tidak, Islam adalah agama yang berhasil menyebar ke seluruh dunia karena dengan argumentasi rasional yang kemudian diterima oleh orang-orang yang berpikir secara rasional pula. Indikasinya adalah bahwa orang-orang Islam tidak pernah memerangi non muslim apalagi melarang mereka untuk melaksanakan ritual agama yang mereka yakini. Begitu pula orang-orang Islam tidak pernah menyakiti mereka apalagi menindas mereka dengan mengusir mereka dari tanah airnya.

Semua itu terjadi karena Allah sendiri memerintahkan kepada orang-orang Islam untuk selalu berbuat baik kepada non muslim baik dalam bentuk perkataan maupun perbuatan selama mereka menjaga nilai toleransi dan tidak melakukan aksi permusuhan. Allah berfirman: "Allah tidak melarang kamu untuk berbuat baik dan berlaku adil terhadap orang-orang yang tiada memerangimu karena agama, dan tidak (pula) mengusir kamu dari negerimu. Sesungguhnya Allah menyukai orang-orang yang berlaku adil. Sesungguhnya Allah hanya melarang kamu menjadikan sebagai kawanmu orang-orang yang memerangimu

${ }^{15}$ Muslim, Saḥih Muslim, jilid 8 (Bayrut: Dār al-Jail, tt.), 22.

${ }^{16}$ Malik bin Anas, al-Muwatta', jilid 2 (Kairo: Dār Ihya Atturath al-Arabi, tt.), 979. 
karena agama dan mengusir kamu dari negerimu, dan membantu (orang lain) untuk mengusirmu. Dan barangsiapa menjadikan mereka sebagai kawan, maka mereka itulah orang-orang yang zalim”. (Qs. al-Mumtahanah [60]: 8-9).

Ayat tersebut seperti yang dijelaskan Imam Ibn al-Jawzī (509-97 H.) merupakan penegasan bolehnya (rukhsah) berinteraksi serta berlaku adil kepada non muslim yang tidak memerangi orang Islam. ${ }^{17}$ Selain itu, ayat tadi juga sifatnya umum. Artinya tidak hanya mencakup agama tertentu seperti yang dijelaskan oleh Ibn Jarir al-Ṭabari $(224-310 \mathrm{H})$ ketika menjelaskan secara transparan pandangan para ahli tafsir mengenai maksud dari orang-orang yang tidak dilarang Allah Swt. berbuat baik kepadanya sesuai dengan kandungan implisit ayat itu sendiri. ${ }^{18}$

Bahkan Allah memerintahkan Rasul-Nya untuk memberikan perlindungan kepada non muslim bila datang meminta perlindungan. Nah, apakah dengan semua teks-teks suci yang disebutkan masih ada yang berasumsi bahwa ajaran Islam identik dengan penindasan, diskriminasi, dan tidak menjunjung tinggi nilai toleransi? Tentu tidak demikian, karena Allah telah memberikan satu rekognisi terhadap masalah ini. Allah berfirman: "Dan jika seorang di antara orang-orang musyrikin itu meminta perlindungan kepadamu, maka lindungilah ia supaya ia sempat mendengar firman Allah, kemudian antarkanlah ia ke tempat yang aman baginya. Demikian itu disebabkan mereka kaum yang tidak mengetahui". (Qs. al-Taubah [9]: 6).

Islam sebagai agama paripurna, mengajarkan perlunya bersifat reseptif terhadap non muslim bila mereka datang kepada orang Islam meminta untuk mendengar ayat-ayat Allah. Orang Islam diperintahkan untuk memberikan keamanan kepada mereka bila ada keinginan mengetahui kebenaran ajaran Islam seperti yang disebutkan Abū Bakr al-Jassas (305-370 H). Allah juga menjelaskan bahwa Nabi hanya diberi tugas menyampaikan dakwah kepada manusia, dan bukan untuk memaksa mereka

${ }^{17}$ Ibn al-Jawzi, jilid 8 "Tafsir Ibn al-Jawre?" (Bayrut: al-Maktab al-Islami, $1404 \mathrm{H}), 237$.

${ }^{18 I b n}$ Jarir, Tafsir Ibn Jarì al-Ṭabari, jilid 28 (Bayrut: Dār al-Fikri, 1405 H), 66. 
mengikuti agama Allah" . Allah berfirman: "Dan jikalau Tuhanmu menghendaki, tentulah beriman semua orang yang di muka bumi seluruhnya. Maka apakah kamu (hendak) memaksa manusia supaya mereka menjadi orang-orang yang beriman semuanya". (Qs. Yunus [10]: 99). Allah juga berfirman: “Tidak ada paksaan untuk (memasuki) agama (Islam), sesungguhnya telah jelas jalan yang benar daripada jalan yang sesat ". (Qs. alBaqarah [2]: 256).

Nabi telah membumikan pesan-pesan tadi dalam interaksinya dengan non muslim, baik ketika beliau mengadakan perjanjian dengan mereka maupun ketika beliau dalam kondisi perang melawan mereka. Ketika delegasi non muslim dari penduduk Najran (Yaman) datang kepada beliau dan bertanya "Bagaimana tentang Isa Ibn Maryam?" Nabi menjawab "Dia adalah rubu al-Läh wa kalimätuh, dan dia adalah hamba dan rasulNya". Lalu mereka berkata kepada Nabi “Apakah engkau siap kami cemoohkan bila jawabanmu ternyata keliru?" Nabi mengatakan "Apakah hal itu yang engkau kehendaki?" Mereka menjawab "Iya". Lalu datanglah pemimpin mereka sembari mengatakan "Jangan engkau cemoohkan lelaki ini, demi Allah jika engkau melakukannya niscaya kita akan dihancurkan". Mereka mengatakan kepada Nabi "Yang mencemoohkan engkau adalah orang-orang bodoh. Kami mohon agar engkau mau memaafkan kami". Nabi lalu mengatakan: "Aku telah memaafkan kalian". 20

Proses penyebaran Islam baik di Asia, Eropa maupun di Afrika, telah tersebar dengan kekuatan argumentasi yang sangat rasional yang membuat para penduduk negeri tersebut terpukau bahwa Islam adalah agama fitrah yang penuh dengan kebenaran yang absolut. Agama yang memiliki ajaran yang kondisional, di mana pun dan kapan pun. Islam adalah agama kemanusiaan yang mengajarkan untuk saling tolong-menolong. Islam adalah agama kebenaran, agama amanah, agama kesetiaan, agama keikhlasan, agama kemanusiaan, agama persaudaraan, agama

${ }^{19} \mathrm{Abū}$ Bakr al-Jassas, Aḅkam al-Qur'àn, jilid 4 (Bayrut: Dār Ihya' alTurath al-'Arabi, 1405), 273.

${ }^{20}$ Alhakim, al-Mustadrak 'Ala al- Șsahihain, jilid 2 (Bayrut: Dār. al-Kutub al-Ilmiah, 1990), 649. 
ketenangan, agama akhlak, agama ilmu pengetahuan, dan agama etika.

Terkait dengan hadis yang banyak disalahpahami orang dan terkadang dijadikan alasan oleh kelompok tertentu bahwa Islam mengajarkan kekerasan dengan dalih hadis yang diriwayatkan Bukhari, Muslim, Tirmidhi, Nasai, al-Darimi, Ibn Majah, Abū Dawud, dan Imam Ahmad. Hadis Nabi yang dimaksud ialah "Aku diperintahkan -kata Nabi- untuk memerangi manusia hingga mereka mengatakan Là Ilāha Illā Allāh". ${ }^{21}$

Secara sepintas memang hadis di atas dapat memicu munculnya misunderstanding terhadap Islam bila hanya dicerna dari segi maknanya karena sangat jelas bahwa yang akan ditangkap ialah bahwa Allah sendiri memerintahkan kepada Nabi-Nya untuk memerangi manusia hingga mereka mau masuk Islam. Pemahaman seperti ini sesungguhnya muncul akibat tidak memahami secara cerdas makna dan maksud daripada kata $\mathrm{Al}$ Nàs. Perlu dimengerti bahwa dalam bahasa Arab "al" (alif lam) yang terambil dari awal "al-Nas" yang berarti manusia adalah merupakan salah satu cara dalam memaknai sesuatu yang diterangkan. Dengan demikian "al' dari kata "al-Nāss" adalah lil ahdi yakni menunjukkan maksud tertentu yakni orang-orang tertentu yang memerangi dan memusuhi orang-orang Islam dengan mengacaukan agamanya serta mengusir mereka dari tanah airnya.

Dengan demikian, hadis tersebut tidak dapat diinterpretasikan secara umum bahwa Nabi diperintahkan oleh Allah untuk memerangi manusia secara keseluruhan, karena yang dimaksud al-Nās atau manusia dalam hadis tadi ialah terbatas pada orang-orang yang secara nyata memusuhi serta memerangi orang-orang Islam. Itulah sebabnya yang diperangi oleh Nabi hanyalah orang-orang yang memerangi umat Islam saja, dan bukan semua orang karena banyak juga non muslim yang toleran dan tidak memerangi orang Islam sehingga dalam konteks agama kelompok yang terakhir ini tidak boleh diperangi kendati mereka bukan orang Islam.

${ }^{21}$ Sulaiman bin Ahmad al-Tabrani, Al-Mu'jam al-Ausat, julid 1 (Kairo: Dārul Haramain, 1415 H), 288. Lihat juga: Abu Dawud, Sunan Abì Dawud, jilid 2 (Bayrut: Dār al-Kitābil 'Arabi, tt.), 1. 
Pemaknaan seperti yang disebutkan banyak dicontohkan di dalam al-Qur'an sebagaimana firman Allah dalam Qs. Ali Imrān (3): 173, terkait dengan maksud kata al-Nàs seperti yang disinggung. Allah berfirman:

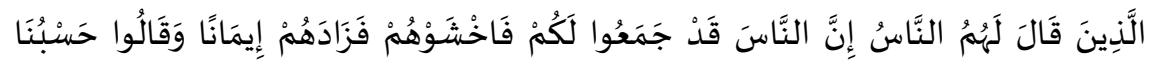

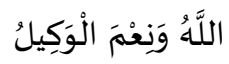

Artinya: "(yaitu) orang-orang (yang mentaati Allah dan Rasul) yang kepada mereka ada orang-orang yang mengatakan: "Sesungguhnya manusia (maksudnya orang Quraysh) telah mengumpulkan pasukan untuk menyerang kamu, karena itu takutlah kepada mereka, maka perkataan itu menambah keimanan mereka dan mereka menjawab: "Cukuplah Allah menjadi penolong kami dan Allah adalah sebaikbaik Pelindung."

Dalam ayat ini sangat jelas bahwa "manusia" yang dimaksud ialah sebatas pada orang-orang tertentu saja dan bukan general. Manusia yang dimaksud dalam ayat tersebut ialah "orang-orang Quraysh". Selain itu dalam proses periwayatan hadis yang disinggung sebelumnya ada penegasan sekaligus perbedaan kata di mana disebutkan dalam riwayat lain tidak memakai kata "alNas" akan tetapi memakai kata "al-mushrikin" yakni orang-orang mushrik. Pada waktu yang sama, Islam dengan tegas menyatakan pelarangannya memerangi orang-orang musyrik yang tidak memerangi orang-orang Islam, apalagi jika ada perjanjian damai yang meliputi para wanita, anak-anak, para lanjut usia, dan para tokoh agama. Jelaslah bahwa Islam tidak mengajarkan agar memerangi agama lain. Dan kelompok yang tidak menerima penegasan ini jelas keliru akibat tidak mengerti makna dan maksud dari hadis-hadis yang erat kaitannya dengan masalah yang sedang dibicarakan.

\section{Perang dalam Agama Islam Sangat Manusiawi}

Dengan sederhana dapat dikatakan bahwa perang merupakan hal yang sangat membahayakan keamanan, tidak hanya kepada kelompok tertentu atau bangsa tertentu, akan tetapi dampaknya dapat mempengaruhi keamanan dunia. Ketika perang meletus maka kondisi pasti berubah menjadi suasana yang menakutkan dan mengerikan. Sebaliknya, bila kedamaian dan perdamaian di tengah-tengah bangsa terjaga dengan baik 
maka tentu tidak ada alasan untuk saling memusuhi apalagi saling memerangi.

Memang, perang di dalam Islam terkadang harus dijalani demi mempertahankan keberlangsungan hidup sekaligus menjaga nilai-nilai keamanan. Bila perang pada kondisi tertentu tidak demikian adanya maka dapat dibayangkan bagaimana kondisi dunia ini, tentu akan dipenuhi dengan kecurangan. Yang kuat menindas yang lemah, sehingga pada akhirnya akan menghancurkan kehidupan manusia itu sendiri karena tidak adanya kekuatan yang dapat membendung atau melawan para penjajah yang haus dengan ketamakan. Dari sinilah, perang di dalam Islam dinilai sebagai kata kunci untuk menjaga keamanan demi melawan ketidakadilan, penjajahan dan kezaliman karena bila kezaliman mendominasi kehidupan suatu bangsa maka pasti yang kuat akan menindas yang lemah.

Nietzsche seorang filosof Jerman dengan amat sederhana memberikan analogi terkait dengan ketidakadilan dan kesewenangan. Dia pernah mengatakan bahwa angin kencang itu selamanya hanya akan menumbangkan pepohonan yang lemah. Itu artinya bahwa ketika perang ditiadakan secara mutlak maka implikasinya juga akan sangat berbahaya karena bangsa yang memiliki kecenderungan menindas bangsa lain akan senantiasa menindas dan menindas.

Karena merasa bahwa tidak satu pun kekuatan yang dapat mengimbanginya akhirnya leluasa melakukan apa saja, akibatnya dunia ini akan semakin mengerikan. Dengan demikian, satu kekuatan dalam kondisi seperti ini sangat diharapkan kehadirannya agar dapat melawan kezaliman, ketidakadilan, dan kesewenang-wenangan. Kehadiran sebuah kekuatan yang dapat mengimbangi kesewenangan dapat menciptakan kedamaian hidup, dan inilah yang diharapkan oleh semua orang. Dan ini pulalah sesungguhnya yang tertuang di dalam al-Qur'an ketika berbicara tentang pentingnya sebuah kekuatan di muka bumi agar tidak terjadi kegoncangan akibat kezaliman merajalela. Allah berfirman: "Dan sekiranya Allah tiada menolak (keganasan) sebagian manusia dengan sebagian yang lain, tentulah telah dirobohkan biara-biara Nasrani, gereja-gereja, rumah-rumah ibadah orang Yahudi dan masjid-masjid, yang di dalamnya 
banyak disebut nama Allah. Sesungguhnya Allah pasti menolong orang yang menolong (agama)-Nya. Sesungguhnya Allah benarbenar Maha Kuat lagi Maha Perkasa”. (Qs. al-Haji [22]: 39-40).

Telah menjadi kenyataan sejarah bahwa perang yang pernah terjadi dan dialami oleh orang-orang Islam tidak satu pun bertujuan untuk menyebarkan fitnah, apalagi menindas bangsa lain. Akan tetapi kesemuanya semata-mata demi menjaga serta mempertahankan nilai-nilai kedamaian dan keamanan karena perang yang dimaksud dilalui berdasarkan petunjuk agama. Betul kalau Nabi dan para sahabatnya pernah mengirim pasukan bala tentara. Namun tujuan pengutusan itu tidak lain kecuali untuk memberantas gerakan bawah tanah yang ingin merongrong Islam baik dari dalam maupun dari luar. Allah menegaskan dalam firman-Nya: "Dan perangilah orang-orang yang memerangi kamu sekalian, dan janganlah kamu sekalian melampaui batas karena sesungguhnya Allah tidak menyukai orang-orang yang melampaui batas". (Qs. al-Baqarah [2]: 190).

Perang tidak dilancarkan dengan begitu saja tanpa ada sebab rasional dan legal secara konstitusi. Penegasan ini tidak hanya dalam konteks agama, tetapi juga dalam konteks hukum konvensional yang ada, dan hanya dilakukan ketika tidak ada solusi lain yang dapat ditempuh selainnya. Secara spesifik dapat dibuktikan dengan hijrahnya Nabi bersama sahabatnya dari Mekah menuju Madinah dengan meninggalkan kampung halaman, keluarga, dan hartanya semata-mata untuk menjaga kondisi keamanan dan kedamaian dengan menghindari bentrok fisik dengan kaum Quraysh pada saat itu. Karena orang-orang Quraysh bersikukuh ingin menindas Nabi bersama sahabatnya kendati telah meninggalkan kampung halamannya yakni Mekah. Akibat para musuh membuntutinya sampai ke Madinah hanya karena kebencian permusuhan yang sudah mendarah daging dalam jiwa mereka sehingga Nabi pun bersama sahabatnya melakukan perlawanan.

Abū Sofyan bin Harb sebagai kepala pasukan Quraysh adalah orang yang paling bertanggungjawab terhadap terjadinya perang Badr antara orang Islam dengan orang-orang Quraysh. Dialah yang mengutus delegasi termasuk Damdam bin Amru ke Mekah ketika serombongan pedagang tiba dari negeri Syam agar 
memberitahukan kepada orang-orang Quraysh bahwasannya Muhammad telah siap siaga bersama sahabatnya untuk menghadang rombongan tersebut. Di samping Abū Sofyan memerintahkan kepada Damdam setibanya di Mekah agar melobangi semua telinga unta-unta yang memikul barang-barang dagangan sekaligus merobek baju-baju mereka dan berteriak ketika mereka sedang memasuki kota Mekah dengan mengatakan: "Tolong! Tolong! Tujuannya agar orang-orang Quraysh yang ada di pelosok Mekah berkumpul lalu kemudian pergi menghadapi orang-orang Islam di mana di antara mereka bergabung seorang yang bernama Suhail bin Amru yang memprovokasi massa dengan mengatakan: "Wahai keluarga Galib, apakah engkau semuanya akan membiarkan Muhammad dan orang-orang yang ada bersamanya dari penduduk Yathrib mengambil harta dan hewan-hewanmu yang membawa banyak barang dagangan? Siapa yang mau harta maka ini harta, siapa yang mau kekuatan pasukan maka ini kekuatan pasukan". 22

Kendati tingkah orang-orang Quraysh seperti itu, namun orang-orang Islam sama sekali tidak melakukan apa yang dikhawatirkan orang-orang Quraysh sehingga ketika Abū Sofyan mengetahui bahwa pihak orang Islam sama sekali tidak melakukan pencekalan dan mengetahui bahwa ternyata usahanya gagal maka Abū Sofyan serentak kembali mengutus delegasi ke Quraysh yakni Qais bin Amru bin Qais agar mereka semuanya kembali ke Mekah dengan mengatakan: "Jangan engkau menjadikan dirimu sekalian sebagai korban penduduk Yathrib. Kendati instruksi itu sudah menyebar namun kaum Quraysh tetap nekad melakukan aksi permusuhannya terhadap Nabi dan sahabatnya sehingga Abū Sofyan lagi-lagi mengatakan ketika mengetahui ambisi tersebut bahwa pasti ini ulah Amru bin Hisham (Abū Jahal) karena dialah yang memimpin orang-orang Quraysh untuk melakukan aksinya.

Melihat kondisi semakin mencekam, Nabi mengutus Umar bin Khattab ke Quraysh untuk menyampaikan kepada mereka agar kembali saja demi menjaga perdamaian dan kedamaian agar

22Lihat: Muhammad Tayyib Najjar, Al-kaulu al-Mubin fi Șirati Sayyid alMursalīn (Bayrut: Dār al-Nadwah Al-jadīdah, tt.), 276. Lihat juga: Ibn Hisham, Assirah Annabawiyah, jilid 4 (Dār al-Jail, 1411 H.), 178. 
tidak terjadi pertumpahan darah. Namun Abū Jahal tetap berambisi dan mengatakan kepada Umar: "Sungguh kami tidak akan pulang kecuali setelah kami berhasil membasmi Muhammad dan para sahabatnya".

Lagi-lagi usaha Nabi tidak hanya sampai di situ, tetapi kemudian mengutus Hakim bin Hizam dan Utbah bin Rabi'ah untuk melakukan pendekatan persuasif kepada orang-orang Quraysh agar mereka betul-betul mau kembali. Namun karena Abù Jahal sangat ambisi dan tetap ingin berperang melawan orang-orang Islam dengan tetap memprovokasi massa sehingga akhirnya terjadilah perang antara kedua kelompok tersebut. Kendati perang terjadi, Nabi dalam hal ini tetap berharap dan optimis agar perdamain tetap ada dan bertahan agar tidak terjadi pertumpahan darah. Dalam perang yang dikenal dengan perang Badar ini, orang Quraysh berhasil dikalahkan oleh orang-orang Islam. Orang Quraysh tidak menerima kekalahan ini, sehingga mereka segera menyusun kembali kekuatan besar untuk menyerang Nabi dan para sahabatnya dengan sebuah keyakinan bahwa mereka mampu meluluhlantahkan Nabi dan sahabatnya. Tetapi Nabi tetap berusaha untuk menghindarinya agar tidak merenggut banyak korban dengan memerintahkan para sahabatnya untuk tetap bertahan di benteng yang ada di Madinah. Jika para musuh masuk ke dalam wilayah orang-orang Islam barulah mereka melakukan perlawanan. Para sahabat khawatir atas instruksi tersebut, karena bisa saja dianggap penakut. Akhirnya Nabi mengabulkan permintaan para sahabatnya agar merespon apa-apa yang diinginkan oleh orangorang Quraysh. Maka tidak ada salahnya jika orang-orang Islam langsung keluar menghadapi para musuhnya yang sangat ambisi menyerang mereka di tempat tinggalnya sendiri untuk mencegah mereka melakukan kesewenangan.

Orang yang mendalami konsep perang di dalam Islam akan senantiasa mengerti bahwa perang tidak lain kecuali sebagai usaha untuk mempertahankan nilai-nilai keadilan dan mencegah terjadinya kezaliman. Dengan perang, orang-orang tidak akan sewenang-wenang memperlakukan orang lain dengan tidak manusiawi. Oleh karenanya perang di dalam Islam tidak lain kecuali untuk melakukan perbaikan dari sebuah kesalahan yang 
terjadi dengan mengembalikan nilai-nilai kadamaian kepada porosnya yang semula. Itulah sebabnya sebuah pernyataan akan sangat keliru bila berasumsi bahwa perang di dalam Islam karena adanya ketamakan menindas orang lain, atau karena adanya faktor ekonomi, atau keinginan untuk melakukan ekspansi.

Karena perang di dalam Islam sangat jelas arahnya seperti yang dipaparkan sebelumnya maka bukan sesuatu yang arogan jika dikatakan bahwa perang dalam Islam mengandung nilai-nilai kemanusiaan yang sangat tinggi. Mengapa tidak, bukankah Islam mengajarkan agar tidak membunuh anak-anak, perempuan, orang lemah, orang lanjut usia, dan para tokoh agama non muslim. Itulah sebabnya kenapa Nabi mengarahkan sekaligus meluruskan perilaku sahabatnya ketika terjadi perang Hunain akibat ada di antara mereka membunuh anak kecil. Karena Nabi tahu adanya perilaku tadi sehingga Beliau pun mengatakan: "Jangan sekali-kali membunuh anak kecil. Usaid bin Al-khudair mengatakan: Ya Rasulallah, anak-anak itu kan anak-anaknya orang mushrik. Nabi pun mengatakan: bukankah orang-orang baikmu sekarang (pembesar sahabat nabi yang muslim) adalah juga anak-anaknya orang mushrik. Sesungguhnya setiap jiwa dilahirkan dalam keadaan suci, orang tuanyalah yang menyebabkan mereka menjadi seorang Yahudi atau Nasrani". 23

Ternyata nilai-nilai kemanusian dalam perang tidak hanya sampai di situ, akan tetapi juga meliputi para tawanan. Tawanan perang dalam pandangan Islam mesti mendapatkan perlakuan khusus yang pada intinya adalah adanya nilai-nilai kemanusiaan tetap harus dijaga sekalipun status mereka sebagai tawanan. Semua itu membuktikan betapa besar perbedaan antara konteks perang dalam Islam dengan perlakuan yang dialami orang-orang Islam dari orang-orang yang benci terhadap mereka. Pesanpesan Nabi terkait dengan bagaimana semestinya seorang muslim berinteraksi dengan orang lain termasuk dengan musuh harus tetap dalam koridor yang manusiawi. Beliau selalu berpesan kepada para sahabatnya dengan mengatakan: "Berperilaku baiklah kepada mereka dengan memberikan

${ }^{23}$ Sulaiman bin Ahmad al-Tabrani, al-Mu'jam al-Kabir, jilid I (Siria: Maktabah al-'Ulum wa al-Hikam, 1983), 283. 
minum, dan jangan mengumpulkan mereka di bawah terik matahari dan panasnya pedang". 24

Dapat dimengerti bahwa Nabi hanya melakukan perlawanan ketika tidak ada solusi lain untuk menghindari terjadinya pertumpahan darah. Karena orientasi perang di dalam Islam untuk melakukan perbaikan, maka tidak ada alasan untuk berlaku curang apalagi melakukan penghancuran. Semua pesan tersebut dapat dibaca mulai dari perang Badar, perang Uhud,

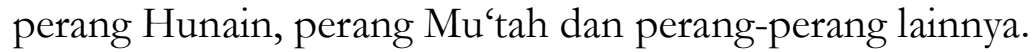

Karena perang di dalam Islam dipenuhi dengan akhlak dan nilai-nilai rahmat, maka para ahli sejarah yang obyektif tidak akan pernah mengingkari bahwa perang sepanjang sejarah Islam telah memberikan contoh adanya sebuah nilai yang penekanannya sangat menghormati hak-hak orang lain kendati mereka itu nyata-nyata adalah musuh. Dari sini pula dapat ditegaskan bahwa perang yang terjadi sepanjang sejarah Islam pada intinya bukan karena dipicu oleh perbedaan agama, akan tetapi karena dipicu oleh rasa kemanusiaan, politik, dan ekonomi. Nabi tidak pernah memaksa orang lain untuk menjadikan Islam sebagai akidah sebagaimana ditegaskan dalam al-Qur'an. Karena itu, perang digolongkan sebagai persoalan furu' dan bukan persoalan ușül.

Dalam pandangan Islam, perbedaan keyakinan sudah merupakan bagian dari sunnah al-Läh di samping sudah menjadi naluri manusia untuk beriman atau tidak beriman. Itulah sebabnya beberapa ulama menegaskan termasuk Muhammad Abduh (1849-1905) bahwa perang yang terjadi antara orang Islam dengan non muslim penyebabnya adalah non muslimlah yang memulai memerangi orang-orang Islam, karena mereka berkeinginan mengembalikan orang Islam ke agama nenek moyang mereka sebelumnya.

Kalau pun mereka tidak memulai melakukan konfrontasi terhadap orang-orang Islam, tetapi indikatornya sangat kuat bahwa usaha mereka mengusir Nabi dari tanah airnya (Mekah), dan menyakiti orang-orang Islam pada saat itu menjadi bukti bahwa merekalah yang menyalakan api permusuhan. Akibatnya

${ }^{24}$ Muh. Abdullah Samman, Al-Islam wa al-Amnu al-Dauli (Kairo: Dār alKutub al-Hadithah, tt.), 230. 
Nabi pun melakukan perlawanan demi menjaga nilai kebenaran dan kehidupan sehingga sangat terlihat bahwa di sisi lain perang hanya dapat dimulai setelah menyampaikan ultimatum kepada musuh. ${ }^{25}$

\section{Pengakuan Para Orientalis}

Sistem yang diusung di dalam Islam terkait dengan perangkat-perangkat perang sudah sangat jelas. Maka dari itu banyak penulis di Eropa mengakui bahwa sesungguhnya sistem perang yang telah diusung oleh orang-orang Islam sangat manusiawi dan paripurna. Beberapa pemimpin tentara dalam perang Salib membunuh para delegesi yang mendatangi mereka dari kalangan orang-orang Islam, dan juga banyak membunuh tawanan perang dari orang-orang Islam. Sementara para pemimpin Islam tidak melakukan hal yang demikian. Orangorang Islam tidak ada yang membunuh delegasi yang diutus oleh musuhnya, apalagi membunuh tawanan perang. Semua itu dilakukan karena Islam memerintahkan untuk memberikan jaminan keamanan jiwa kepada para delegasi itu hingga mereka sampai ke tempatnya yang semula termasuk juga ketentuan hukum terkait dengan tawanan perang. Pengakuan tersebut telah disebutkan oleh beberapa orientalis Barat di antaranya:

- Sir Thomas Arnold. Mengatakan: "Sesungguhnya Islam telah membawa kehidupan baru yang terbangun atas dasar kebebasan beragama yang sama sekali tidak pernah dirasakan oleh non muslim beberapa abad sebelumnya. Dan sesungguhnya opini yang merebak bahwa Islam tersebar dengan kekuatan pedang sehingga banyak orang masuk agama Islam adalah pernyataan yang sangat keliru dan tidak benar". ${ }^{26}$ Dia juga mengatakan: "Sungguh orang-orang Islam telah memperlakukan orang-orang Masehi (Kristen) dengan

${ }^{25} \mathrm{Apa}$ yang dijelaskan di dalam Islam terkait dengan perlunya memberitahukan kepada musuh sebelum adanya penyerangan, baru dikenal di dalam hukum internasional setelah adanya perjanjian LAHAI 1907 tentang pentingnya memberi peringatan kepada musuh sebelum melakukan agresi militer.

${ }^{26}$ Sirt Thomas Arnold, Al-Da'wah Ila al-Isläm (Kairo: Maktabah alNahḍah al-Mașriyah, 1957), 123. 
sangat toleran sejak abad pertama hijriah, dan rasa toleran itu berlangsung pada abad-abad berikutnya. Dan kami dapat memastikan dengan penuh kebenaran bahwa kabilah-kabilah masehi yang telah memeluk agama Islam, mereka telah memeluknya dengan kemauan sendiri tanpa ada paksaan. Dan sesungguhnya orang-orang Arab Masehi yang hidup di masa kita sekarang ini di tengah-tengah komunitas Islam adalah merupakan indikasi nyata adanya rasa toleransi“ “. ${ }^{27}$

- Thomas Kariel seorang penulis dan filosof berkebangsaan Inggris menulis tentang sosok pribadi Nabi dalam sebuah bukunya yang kemudian diterjemahkan ke dalam bahasa Arab "al-Abtal wa Ibadab al-Butulah". Dalam buku tersebut, Thomas menjadikan Nabi sebagai seorang pahlawan dan seorang manusia yang tidak ada bandingannya dalam hal kesempurnaan dan loyalitas. Dia mengatakan: "Kekeliruan orang-orang yang tidak memahami, menuduh Muhammad (Rasulullah Saw.) bahwa dia sangat berpegang pada kekuatan pedang dalam penyebaran dakwahnya. Bagaimana mungkin hal itu dianggap rasional. Dia hanya sendirian mengangkat pedangnya di depan orang banyak agar mereka mau menerima ajakan dakwahnya. Maka jika ada orang yang beriman kepadanya dari orang-orang yang memiliki kemampuan memusnahkan musuh-musuh mereka maka sesungguhnya mereka beriman kepadanya dengan penuh kerelaan hati dan membenarkan ajarannya. Dan mereka orang-orang Islam yang beriman kepadanya telah banyak mengalami cemoohan dan siksaan serta serangan dari para musuhnya sebelum mereka orang-orang Islam mampu berperang dan melakukan perlawanan", ${ }^{28}$

- Gustave Lebon. Ketika menjelaskan tentang rahasia menyebarnya dakwah Islam di masanya dan di masa pembukaan beberapa negeri setelahnya. Beliau menegaskan bahwa: "Sejarah telah menunjukkan bahwasanya agamaagama yang ada tidak menggunakan pemaksaan dan kekuatan, dan Islam sendiri tidak tersebar dengan pedang.

${ }^{27}$ Ibid., 51 .

${ }^{28}$ Muh. Atiyah al-Abrashi, Al-Damah al-Isläm, jilid 2 (Kairo: Maktabah alUsrah, 2005), 16. 
Akan tetapi tersebar dengan dakwah semata. Dengan dakwah para penduduk negeri memeluk agama Islam yang telah menindas orang-orang Arab sebelumnya seperti orang-orang Mongol. Dan al-Qur'an sendiri telah tersebar di negeri India sehingga penduduk negeri tersebut memeluk agama Islam yang jumlahnya melebihi 50 juta jiwa. Dan Islam sendiri telah tersebar di negeri China dimana negeri tersebut satu pun wilayahnya sama sekali tidak pernah dibuka oleh orang-orang Arab". ${ }^{29}$ Gustave Lebon juga mengakui bahwa sesungguhnya dunia ini tidak pernah mengenal pembuka sebuah kota atau negeri yang lebih penyayang dari orang-orang Islam. Kemudian ia membandingkan dengan apa yang dilakukan oleh Richard dengan apa yang dilakukan oleh Șalahuddīn alAyyuby dalam perang Salib. Beliau mengatakan: "Masalah yang pertama kali dilakukan oleh Richard adalah membunuh 3000 tawanan perang yang menyerahkan diri setelah ia berjanji pada dirinya untuk menjaga darah mereka kemudian menyalahi janjinya dengan melakukan pembunuhan massal dan perampokan sehingga mengakibatkan cucu Șalahuddin Al-Ayyuby sangat marah karena mereka sama sekali tidak menyakiti orang-orang Nasrani sedikit pun, bahkan beliau mengobati Richard dengan memberikan obat kepadanya ketika sakit. ${ }^{30}$

- Montih Edwar (1856-1928) seorang orientalis Prancis yang banyak menggeluti teologi Nasrani dan ilmu-ilmu ke-Islaman. Ia menyatakan akan ciri khas Islam secara spesifik yang menarik perhatian orang Nasrani yang ada di belahan Timur bahwasannya: "Islam pada dasarnya adalah agama rasional, dan sesungguhnya pemaknaan rasionalisme bahwa itu adalah sebuah cara menegakkan teologi agama atas dasar prinsipprinsip rasional sangat sesuai dengan akidah Islam". 31

- Christopher Dauson (1867-1900). Menegaskan bahwa Islam adalah agama yang indevenden dari dua agama sebelumnya yakni Yahudi dan Nasrani. Dan dengan jujur kami katakan 128.

${ }^{29}$ Gustave Lebon, Hadarah al-'Arab (Kairo: Maktabah al-Usrah, 2000),

${ }^{30}$ Ibid., 407.

${ }^{31}$ Sirt Thomas Arnold, Al-Da'wah ......., 454. 
bahwa sungguh benar bahwa Islam melebihi kedua agama sebelumnya" 32 .

- Kepala pendeta Isyoyabah yang diangkat pada tahun 647-657 H. Mengatakan bahwa: "Orang-orang Arab yang diberi oleh Tuhan kesempatan menguasai dunia telah memperlakukan kami dengan sebaik-baiknya. Orang Islam bukan musuh orang-orang Nasrani. Orang Islam sangat menghargai agama kami dan menghargai para pendeta-pendeta kami, sekaligus memberikan kepada kami bantuan untuk rumah ibadah kami dan agama kami", 33

Karena kedamaian sangat berpengaruh terhadap perang, maka Islam adalah agama damai. Bila perang tidak mendatangkan kebajikan dalam kehidupan maka perang tersebut menjadi sesuatu yang sangat keji, karena Islam adalah agama yang mengajak kepada keteladanan dalam setiap interaksi yang dilakukan manusia. Bagaimana mungkin Islam bukan agama keselamatan sementara salah satu nama Allah adalah al-salam (keselamatan), begitu juga orang-orang Islam mengatakan dalam salatnya ketika tashabud "al-salam 'alayk ayyuha al-naby wa rabmatu al-Läh wa barakätuh, al-salàmu 'alayna wa 'ala 'ibadi Al-Läh alsalibin" (keselamatanlah atasmu wahai Nabi serta rahmat dan berkah Allah menyertaimu, keselamatan pula atas kami dan atas hamba-hamba Allah yang saleh).

Kemudian setelah itu, orang Islam dalam mengakhiri salatnya juga mengatakan al-salamu 'alaykum (keselamatan atas kamu sekalian). Bagaimana mungkin Islam bukan agama keselamatan sementara al-Qur'an sendiri menamakan surga sebagai daru al-salamm (tempat keselamatan). Allah berfirman "Bagi mereka (disediakan) daru al-salàm (surga) pada sisi Tuhannya dan Dia-lah pelindung mereka disebabkan amal-amal saleh yang selalu mereka kerjakan”. (Qs. al-An'am [6]: 127). Lalu kemudian al-Qur'an menjadikan penghormatan di dalam surga menjadi kata "keselamatan". Allah berfirman "(yaitu) orangorang yang diwafatkan dalam keadaan baik oleh para malaikat

${ }^{32}$ Muhammad Imarah, al-Isläm $W$ a al-kaliyyat (Kairo: Maktabah alShshuruk al-Dawliah, 2003), 146. 149.

33Tartun, Abl Azæimmah fì al-Islām (Kairo: Dār al-Fikr al-'Arabiy, tt.), 
dengan mengatakan (kepada mereka): "Salämun 'alaykum, masuklah kamu ke dalam syurga itu disebabkan apa yang telah kamu kerjakan”. (Qs. al-Nahl [16]: 32).

Dan ketika Allah mensifati orang-orang mukmin yang bertakwa dengan kata "keselamtan". Allah berfirman "Dan hamba-hamba Tuhan yang Maha Penyayang itu (ialah) orangorang yang berjalan di atas bumi dengan rendah hati dan apabila orang-orang jahil menyapa mereka, mereka mengucapkan katakata (yang mengandung) keselamatan". (Qs. al-Furqān [25]: 63).

Sudah dibuktikan betapa orang-orang Islam tidak berperang kecuali hanya untuk melawan serangan atas mereka, negara mereka, dan akidah mereka. Mereka tidak menghunus pedangnya kecuali pada kondisi genting di mana para musuh tidak mau berdamai. Mereka tidak berperang kecuali orangorang yang memerangi mereka. Mereka tidak melampaui batasbatas kewajaran dalam perang kecuali hanya sekedar melakukan perlawanan terhadap serangan musuh. Mereka berperang sangat menghormati para korban di mana mereka tidak diperbolehkan memutilasi para korban dan tidak merusak apalagi memaksa seseorang untuk meninggalkan agamanya agar masuk Islam. Sudah dibuktikan bahwa orang-orang Islam memperkuat diri bukan untuk memaksa orang lain menyerah.

Dengan demikian sangatlah jelas bahwa ajaran toleransi di dalam Islam yang kemudian dibumikan para pemeluknya adalah rahasia utama orang-orang Islam meraih kemenangan dan keberhasilan membuka beberapa negeri dengan tidak mendapatkan perlawanan dari penduduk setempat. Ini adalah salah satu rahasia yang tidak sempat ditangkap oleh Napoleon Bonaparta dalam pembacaannya ketika menganalisa tentang rahasia mengapa Islam tersebar dengan begitu cepat. Napoleon mengatakan: "Sesungguhnya ada rahasia di balik menyebarnya Islam dengan begitu cepat yang kita tidak ketahui. Di samping ada pula sebab-sebab yang kita tidak ketahui membuat orangorang Islam dapat mengalahkan orang-orang Kristen. Barangkali rahasia yang kita tidak ketahui itu adalah bahwasanya orangorang Islam yang tiba-tiba muncul dari dalamnya padang pasir telah terlatih dengan perang saudara yang berkepanjangan 
sehingga membuat mereka punya keteguhan hati yang begitu kuat, kemampuan yang cerdas dan semangat yang luar biasa“. ${ }^{34}$

Islam menyebar di kota Mekah sementara Nabi dan sahabatnya masih tergolong sedikit jumlahnya. Nabi dan sahabatnya tidak memiliki kekuatan yang dapat melindungi jiwa mereka dari tekanan dan penindasan para musuh. Begitu pula Islam menyebar di Madinah sebelum Nabi hijrah, dan orangorang muslim Madinah berjanji akan melindungi, membantu serta menolong Beliau jika Beliau hijrah ke negeri itu. ${ }^{35}$

\section{Catatan Akhir}

Kendati semua yang disebutkan sangat jelas, tetapi masih saja ada orang yang fanatik akibat tidak mengerti hakekat risalah Islam yang sebenarnya sebab ingin selalu menjadikan Islam sebagai bagian dari persengketaan sekaligus sebagai subjek dalam setiap peperangan dan kerusuhan yang terjadi sehingga sangat disayangkan karena telah memancing munculnya sebuah opini bahwa Islam menyebar karena kekuatan pedang, dan Islam selalu mengajak berperang dan melakukan tindak kejahatan, kekerasan, dan anarkis. Untuk membantah opini tadi cukup dengan mengatakan bahwa Allah dan Rasul-Nya memerintahkan orang-orang Islam agar senantiasa berlaku adil dan tidak mencampuradukkan antara kebenaran dengan kebatilan. Allah mempertegas hal itu dalam al-Qur'an "Hai ahli kitab, mengapa kamu mencampuradukkan yang hak dengan yang batil, dan menyembunyikan kebenaran, padahal kamu mengetahuinya". (Qs. Ali Imrān [3]: 71). Wa al-Lāh a lam bi al-ṣawāh.

\section{Daftar Pustaka}

al-Abrashī, Muḥammad 'Ațiyah. 2005. Al-Ḍamah al-Islām. Kairo: Maktabah al-Usrah.

Arnold, Sir Thomas. 1957. Al-Dáwah ilà al-Isläm. Kairo: Maktabah al-Nahḍah al-Mașriyyah.

${ }^{34}$ Ahmad Muhammad al-Haufi, Samahatu al-Islām (Kairo: Wizārah alAwkaf, 2003), 213.

35Ibid., 72 . 
al-Bukhārī, Imām. 1987. Saḅih al-Bukhārī. Bayrūt: Dār ibn Kathīr.

Dāwūd, Abū. tt. Sunan Abi Dāwūd. Bayrūt: Dār al-Kitāb al'Arabī.

Hajar, Ibn. 1379 H. Fath al-Bārì. Bayrūt: Dār al-Ma'rifah.

al-Ḥākim. 1990. Al-Mustadrak 'ala al-Ṣahīḥayn. Bayrūt: Dār alKutub al-'Ilmiyyah.

al-Haufi, Aḥmad Muḥammad. 2003. Samāḥah al-Isläm. Kairo: Wizārah al-Awkaf.

Haykal, Muhammad Husayn. 1361 H. Al-Ṣiddīq Abū Bakr. Kairo: Matba'ah Mișr.

Hef, Abū. 1959. Al-Qānūn al-Dawlì al-'Āmm. jilid 4. Kairo: Mansha'ah al-Ma'ārif.

Hibban, Ibn. 1993. Șaḅiḩ ibn Hibbān’. Bayrūt: Mu'assasah alRisālah.

Hishām, 'Alā' al-Dīn 'Alī bin. 1981. Kan₹ al-Ummah. Bayrūt: Mu'assasah al-Risālah.

Hishām, Ibn. 1411 H. Al-Sìrah al-Nabawiyyah”. Bayrūt: Dār alJail.

al-Humaydi, Muhammad bin Futuh. 2002. Al-Jam' Bayn alSabīhayn al-Bukhārì wa Muslim. Bayrūt: Dār ibn Hazm.

Imārah, Muhammad. 2003. Al-Islām wa al-Akalliyāt. Kairo: Maktabah al-Shuruk al-Dawliyyah.

al-Jassas, Abū Bakr. 1405 H. Aḅkeàm al-Qur'ān. Bayrūt: Dār Ihyāà al-Turāth al-'Arabī.

al-Jawziyyah, Ibn Qayyim. 1404 H. Tafsìr ibn al-Jawrì. Bayrūt: alMaktabah al-Islāmī. . 1992. Rawdah al-Muhibbiñ”. Bayrūt: Dār al-Kutub al-'Ilmiyyah. 1994. Zād al-Ma'ād. Jilid 3. Bayrūt: Mu’assasah alRisālah.

Khallaf, 'Abd al-Wahhāb. 1988. Al-Siyāsah al-Shar'iyyah”. Kairo: Dār al-Qalam.

Lebon, Gustave. 2000. Hadarah al-'Arab. Kairo: Maktabah alUsrah.

Malik, Anas bin. tt. Al-Muwaț̣a'. Kairo: Dār Iḥyā' al-Turāth al'Arabī.

Muslim, Imām. tt. Șạ̣ị̣ Muslim. Bayrut: Dār al-Jail. 
Najjar, Muhammad Ṭayyib. tt. Al-Qawl al-Mubin fi Sirah Sayyid alMursalìn. Bayrut: Dār al-Nadwah al-Jadīdah.

al-Nawawī, Imām. 1392 H. Sharḥ Ṣahịh Muslim. Bayrūt: Dār Iḥyā' al-Turāth al-'Arabī.

al-Qarafi. 1998. Anwār al-Burūk fì Anwāi al-Furūk. Bayrūt: Dār alKutub al-Ilmiah.

Samman, Muḥammad 'Abd al-Lāh. tt. Al-Islām wa al-Amn alDawlì. Kairo: Dār al-Kutub al-Hadīthah.

Sharif, a-Mustashar Umar. 1986. Al-Huk.m wa al-Idàrah fi alDawlah al-Islämiyyah. Kairo: Ma‘had al-Dirāsāt alIslāmiyyah.

al-Ṭabarī, ibn Jarīr. 1405 H. Tafsir ibn Jarìr al-Ṭabarì. Bayrūt: Dār al-Fikr.

al-Ṭabrānī, Sulaymān Aḥmad. 1415 H. Al-Mưjam al-Awsat. Kairo: Dār al-Haramain.

. 1983. Al-Mu'jam al-Kabir. Siria: Maktabah al'Ulūm wa al-Hikām.

Tartun. tt. Abl al-Zimmah fì al-Islām. Kairo: Dār al-Fikr al-'Arabi. 